\title{
The effects of temperature on the characteristics of kaolinite and bentonite
}

\author{
Gulgun Yilmaz \\ Anadolu University, 26470 Eskişehir, Turkey. E-mail: guunal@anadolu.edu.tr. \\ Accepted 20 October, 2010
}

\begin{abstract}
In this study, kaolinite and bentonite were investigated for the effect of thermal treatment on particle size, as well as water content, specific gravity, plasticity, activity index, swelling and compression index and strength properties. At first, kaolinite and bentonite were characterized using XRD and TG standard methods. All sieved samples were subsequently heated to various temperatures $(100,200$, 400,500 and $600^{\circ} \mathrm{C}$ respectively), and kept for $24 \mathrm{~h}$ at the maximum temperature. Odometer cells were used to describe the compressibility properties (loading and unloading) of the compacted-treated samples. Triaxial compression tests were carried out to determine thermal treatment effects on the strength parameters of all samples. It was found that kaolinite becomes non-plastic at $400^{\circ} \mathrm{C}$ and bentonite at $500^{\circ} \mathrm{C}$. Grain size growth with increasing thermal treatment plays indeed a major role. Thermal treated kaolinite and bentonite up to $400^{\circ} \mathrm{C}$ drastically reduces their swelling behavior. Strong correlations between the angle of shearing resistance and thermal treatment of both materials and correlation coefficients have been demonstrated. The results showed that kaolinite and bentonite can be used as good stabilization materials if they are thermal treated; kaolinite up to $400^{\circ} \mathrm{C}$ and bentonite up to $500^{\circ} \mathrm{C}$.
\end{abstract}

Key words: Kaolinite, bentonite, thermal treatment, index properties, scanning electron microphotograph.

\section{INTRODUCTION}

Thermal treatments on kaolinite and bentonite are important for specific applications of clays. Interest in the topic goes back to the sixties, when the first conference concerning "the effect of temperature and heat on engineering behavior of soils" was held in Washington in 1969. Recent research is mainly concerned with nuclear waste isolation (Laloui and Modaressi, 2002) and the use of soil deposits for heat energy storage. Some other applications are related to geothermal structures (Lauloui et al., 2003), petroleum drilling, injection and production activity (Dussealut et al., 1988) and zones around buried high-voltage cables (Mitchell et al., 1982). In general many research has shown that an increase in temperature affects clay properties (plasticity, water content, permeability, swelling, elastic modulus, etc). A review of this subject has been carried out by Laloui and Cekerevac (2003). Engineering properties of clays vary with the type, mineralogy, chemical composition, density and water content of clay (Wang et al., 1990). Thermal treatment strongly affects the behavior of clays through its influence on free and adsorbed water. Thermal strain is caused in clay structures mainly by the expansion of the free water and the changes in adsorption forces in the adsorbed water. Due to the thermo-mechanical deformation of the solid skeleton, the hydraulic gradient and transitory flow of pore water are also modified. The combined effects of these phenomena in both drained and undrained conditions are discussed by Laloui and Cekerevac (2003). This is especially important for clay based grounds where clay rapidly interacts with water.

The magnitude of thermal changes in clay body largely depend on the mechanical and mineralogical make up of clay mass, besides temperature of exposure and its duration, fabric of clay mass and interparticle separations (Bhatnagar and Goel, 2002). Soil stabilization by means of heating has been widely applied to a large variety of engineering projects which are conducted to improve properties of soft, swelling, compressible and collapsible soils and used for slope stabilization (Chandrasekhran et al., 1969). Clay undergoes two main reactions: one of which is the removal of physical water at $100^{\circ} \mathrm{C}$ and the second one is neoformation with the depleting of 
chemically bound $\mathrm{OH}$ groups in the temperature range between 500 to $100^{\circ} \mathrm{C}$. Atterberg limits widely vary depending on soil type (Chandrasekhran et al., 1969). Since clays show non-plastic behavior at different temperatures, determination of the Atterberg limits cannot be easily made. Heating of clays has a positive effect on the degree of cohesion between clay particles resulting in increase of angle of shear resistance (Litvinov, 1960) and in compressive strength, especially of high plasticity clay based soil.

The purpose of this paper is to present thermal treatment for kaolinite and bentonite. In the present study kaolinite supplied by ceramic factory and bentonite of Eskişehir region of Turkey (Yilmaz, 1999) are investigated for the effect of thermal treatment on particle size, as well as Atterberg limits, specific gravity, activity, swelling and compression index and strength properties.

\section{Effect of thermal treatment on engineering properties of clays}

Thermal treatment of clays can lead to changes in the chemical and physical structures. While the temperature effect is quite straight forward in relatively pure clay-water systems within a limit range of temperature, it may cause dispersion or flocculation effects depending on clay mineral and type of exchange ion. Different temperature ranges in which significant changes occur in the structures of clay minerals may be distinguished.

\section{Dehydration of clays}

The moisture content has a strong influence on the engineering behavior of clays. Temperatures above dehydration but below dehydroxylation: when the temperature is raised from ambient to that of the onset of dehydroxylation, clays lose adsorbed and hydration water. As a result, the interlayer spaces collapse, while pore space is changed, and the acidity of the clay mineral surfaces and interlayer's is substantially altered. Loss of adsorbed water alters the macro and micro porosity of the clay mineral as well as its plasticity. Temperatures above dehydroxylation, but below those leading to complete destruction of the structure: the changes occurring in this temperature range vary for different clay mineral groups. Dehydroxylation destroys the layer structure of trioctahedral, 2:1 type (T-O-T) minerals, whereas that of their di-octahedral counterparts is preserved. Kaolinite group minerals become amorphous to X-rays although some features of the structural framework are preserved (Heller-Kallai, 2006).

\section{Atterberg limits and unit weight}

Temperature changes influence the liquid and plastic limits proportional to the change with thermal treatment in the viscosity of water. Some researchers tested kaolinitic, illitic, and montmorillonitic clays and found their liquid and plastic limits decreased with an increase in temperature. Thermal treatment has an effect on the consistency limits and unit weight relationship, particularly for clays (Fang and Daniels, 2006).

\section{Compressibility and volume change}

In general, the effects of thermal treatment on compressibility and volume change include: a) an increase in compressibility with increase in temperature, the compression index, Cc, increased radically between 4.4 to $21.1^{\circ} \mathrm{C}$; b) decrease in clay volume with increase in temperature at constant pressure with the temperature being the only external variable; $c$ ) temperature increases caused immediate volume changes with magnitudes dependent upon the magnitude of the temperature change (Fang and Daniels, 2006).

\section{MATERIALS AND METHODS}

In this study two different clays are used. Samples of kaolinite and bentonite were sieved to pass 200 mesh $(<75 \mu \mathrm{m})$. This powdered samples were dried at $110^{\circ} \mathrm{C}$ during $24 \mathrm{~h}$. Aliquots of dried sample (1 to $2 \mathrm{~g}$ ) were gently ground using an agate mortar for further analysis. Chemical composition of clay samples were conducted through XRD and XRF and sample preparation techniques as mentioned in standards for clay materials were followed (Bhatnagar and Goel, 2002). Chemical compositions were obtained by X-ray fluorescence (XRF) analysis using a sequential spectrometer (Siemens SRS-3000). XRD analysis of the samples were performed using Rigaku RINT-2200 diffractometer in a scanning range of 5 to $40^{\circ}(2 \theta)$ at a rate of $2^{\circ}(2 \theta) \mathrm{min}^{-1}$. Cu Ka radiation was used. Thermogravimetric analysis (TG) curves were measured from 30 to $600^{\circ} \mathrm{C}$ at a rate of $10^{\circ} \mathrm{C} \mathrm{min}^{-1}$ with Setsys Evolution Setaram thermal analysis apparatus. All sieved samples were subsequently heated to various temperatures $\left(100,200,400,500\right.$ and $600^{\circ} \mathrm{C}$ respectively) and kept for $24 \mathrm{~h}$ at the maximum temperature. In order to prevent water absorption after cooling, all treated samples were stored in desiccators. Particle size distribution analyses of raw samples were carried out (Mastersizer X lazer, Malver Instruments), after sieving and dispersion in aqueous medium using sodium hexametaphosphate as dispersant.

The physical properties of raw and treatment samples were complemented with the determination of the consistency limits of remolded states (liquid and plastic limits), and another particle-size analysis was made with sieve and hydrometer methods and the density of all samples using water picnometry, according to the procedures outlined in ASTM Standards (ASTM D-2216, 1986; ASTM D-845, 1986; ASTM D-421, 2007; ASTM D-422, 2007; ASTM D- 4318, 1986; ASTM D-698, 1986) and Yilmaz (2003). Mechanical tests were carried out at standard compaction state to explore the volume change, compressibility and strength properties. For consolidation and three axial compressive strength values, specimens were prepared at standard proctor (SP) conditions (ASTM D-698, 1986; Craig, 1992). Odometer cells were used to describe the compressibility properties (loading and unloading) of the compacted-treated samples at "standard proctor" conditions. For strength properties, triaxial compression tests were performed on all treated samples at SP. Triaxial compression tests (with 68, $95,172,38$ and $275,80 \mathrm{kN} / \mathrm{m}^{2}$ confining pressures) were carried out 
Table 1. Chemical analysis of raw materials (Yilmaz, 1999; Yilmaz, 2003).

\begin{tabular}{lcc}
\hline Constituent (\%) & Kaolinite & Bentonite \\
\hline $\mathrm{SiO}_{2}$ & 50.16 & 61.08 \\
$\mathrm{Al}_{2} \mathrm{O}_{3}$ & 39.41 & 21.90 \\
$\mathrm{Fe}_{2} \mathrm{O}_{3}$ & 0.68 & 3.25 \\
$\mathrm{CaO}$ & 5.10 & 5.23 \\
$\mathrm{MgO}$ & 0.40 & - \\
$\mathrm{Na}_{2} \mathrm{~K}_{2} \mathrm{O}$ & - & 3.59 \\
$\mathrm{P}_{2} \mathrm{O}_{5}$ & 0.04 & - \\
$\mathrm{K}_{2} \mathrm{O}$ & 0.92 & - \\
\hline
\end{tabular}

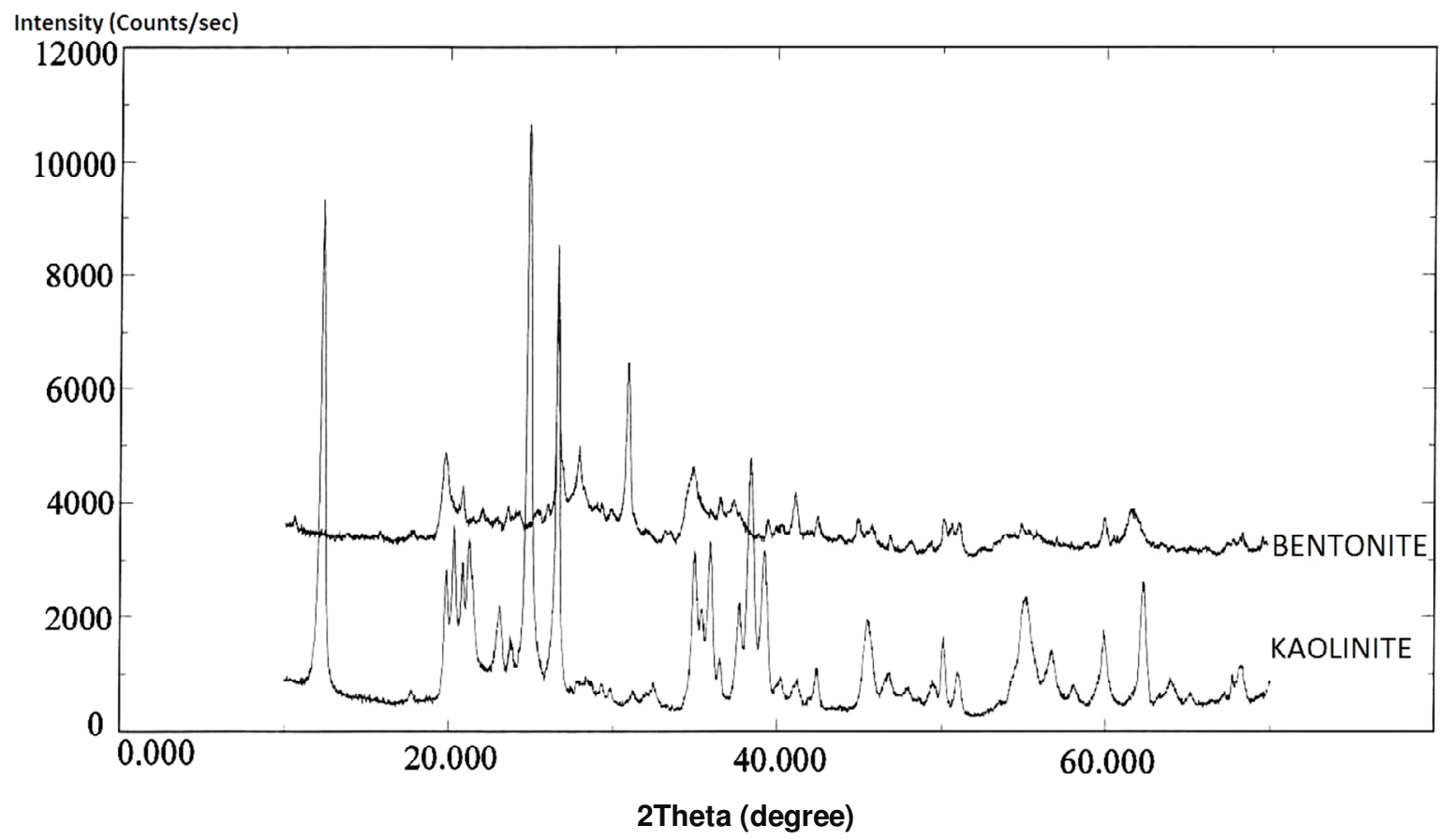

Figure 1. XRD Analysis (Yilmaz, 2003).

to determine thermal treatment effects on the strength parameters of all samples.

\section{RESULTS AND DISCUSSION}

\section{XRF and XRD studies}

The chemical compositions of raw samples, determined by XRF (Table 1) are in well agreement with the mineralogical composition as seen by XRD (Figure 1) (Yilmaz, 2003). The results for kaolinite, expressed in oxide percentage, confirm the presence of silica (50.16\%) and alumina $(39.41 \%)$ from the silicates and quartz present. Kaolinite has calcium oxide content at around $(5.1 \%)$, as well as iron and magnesium oxides (both around $0.5 \%)$. Bentonite has silica (61.08\%) and alumina $(21.90 \%)$ from the silicates and quartz, calcium oxide content at around (5.23\%), as well as iron oxide (both around $3.25 \%$ ), the constituents comprising the remaining $5 \%$ being hardly relevant (Table 1 ). These chemical compositions were checked by EDX analysis. $X$-ray diffraction analysis (XRD) results for two raw samples are given in Figure 1. The specimen's X-ray diffraction analysis showed that they contain kaolinite, illite and shapeless particles of quartz.

\section{TG analysis}

TG curves for raw materials (Figure 2) exhibited a single weight loss between 400 and $600{ }^{\circ} \mathrm{C}$ whereas that for kaolinite and bentonite exhibited two steps. The first step, between 100 and $400^{\circ} \mathrm{C}$, can be assigned to the release of water formed through interlayer of kaolinite and bentonite and the second, above $400^{\circ} \mathrm{C}$, to the loss in the 


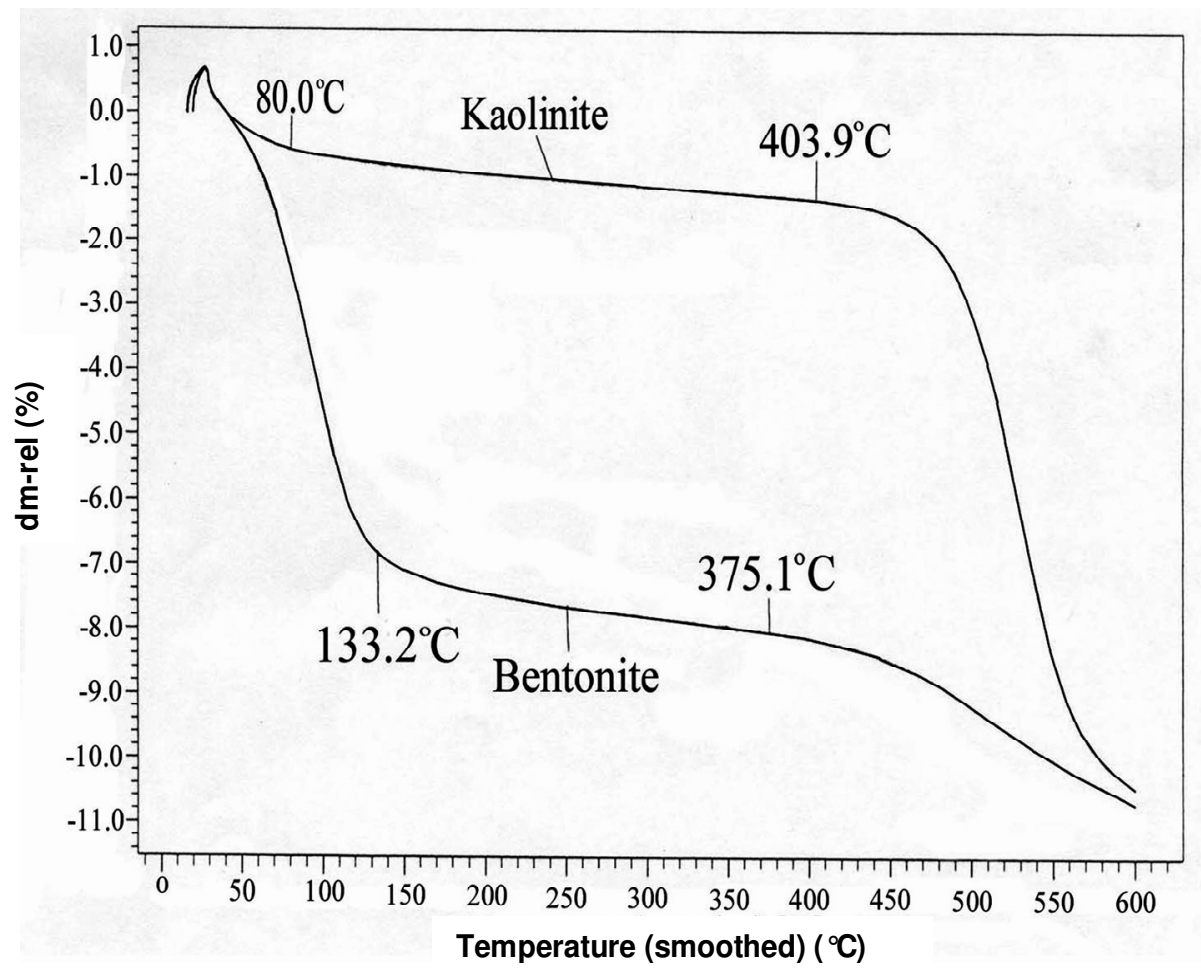

Figure 2. TG Analysis.

Table 2. Index properties of raw materials (Yilmaz, 2003; Yilmaz, 2004).

\begin{tabular}{lcc}
\hline Sample & Kaolinite & Bentonite \\
\hline Specific gravity (Gs) & 2.55 & 2.65 \\
Clay (\%) & 55 & 75 \\
Silt (\%) & 45 & 22 \\
Sand (\%) & - & 3 \\
Liquid Limit (LL) (\%) & 45 & 158 \\
Plastic Limit (PL) (\%) & 31 & 45 \\
Plasticity Index (PI) (\%) & 14 & 113 \\
\hline
\end{tabular}

thermal dehydroxylation process. As can be seen in Figure 2, the first and second weight loss varied with temperature. Thermogravimetric analysis (TG) studies indicated that kaolinite specimens seem to lose $9 \mathrm{wt}$. \% at temperatures between 400 and $600^{\circ} \mathrm{C}$. Bentonite specimens have greater potential to hold water. Interlayer water is lost at temperatures between 80 and $100^{\circ} \mathrm{C}$. The percentage of interlayer water is estimated as $1 \mathrm{wt}$. \% in kaolinite and $7.5 \mathrm{wt}$ \% in bentonite. As a result, the weight loss rate increased with increasing temperature beyond the temperature range 400 to $600^{\circ} \mathrm{C}$ for kaolinite (Yilmaz, 2003). But this rate is absorbed to be much slower for bentonite for the same temperature range. Kaolinite and betonite structures had been both partially destroyed; however due to weaker bonds between hydroxyl groups, bentonite at low temperatures goes through a more rapid loss of weight compared to kaolinite.

Particle size distribution, clay-silt size, uniformity coefficient, specific gravity, activity

The particle-size distribution by sieve and hydrometer analysis displayed a range of sizes from sand to clay sizes, as shown in Table 2 (Yilmaz, 2004). Consistency limits of raw materials shown in Table 2 correspond to a medium activity kaolinite $(A=0.25)$ with low liquid limit and plasticity index, which could be classified as inorganic clay and bentonite $(A=1.5)$ with high liquid limit and high plasticity inorganic clay according to the Unified Soil Classification System (ASTM D-421, 2007; ASTM D422, 2007). Particle size curves of kaolinite and bentonite thermal treated at different temperatures are presented 


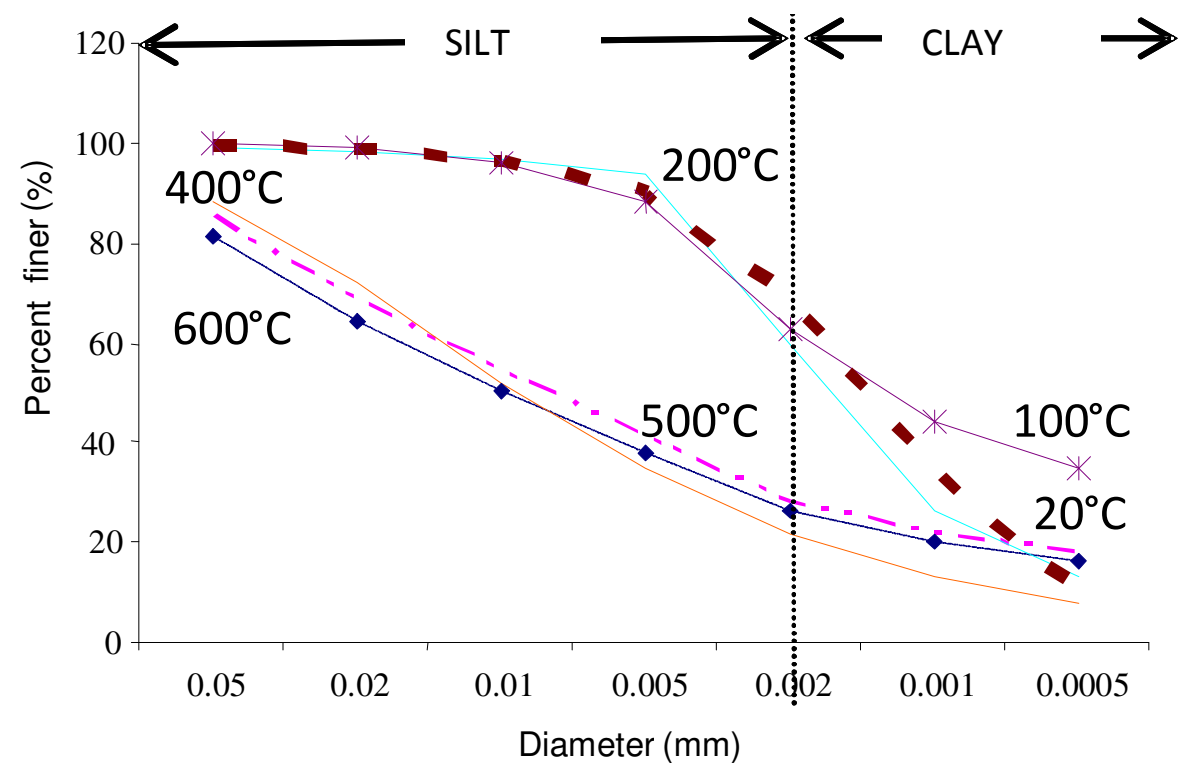

Figure 3. Particle size curves of treated kaolinite at different temperatures.

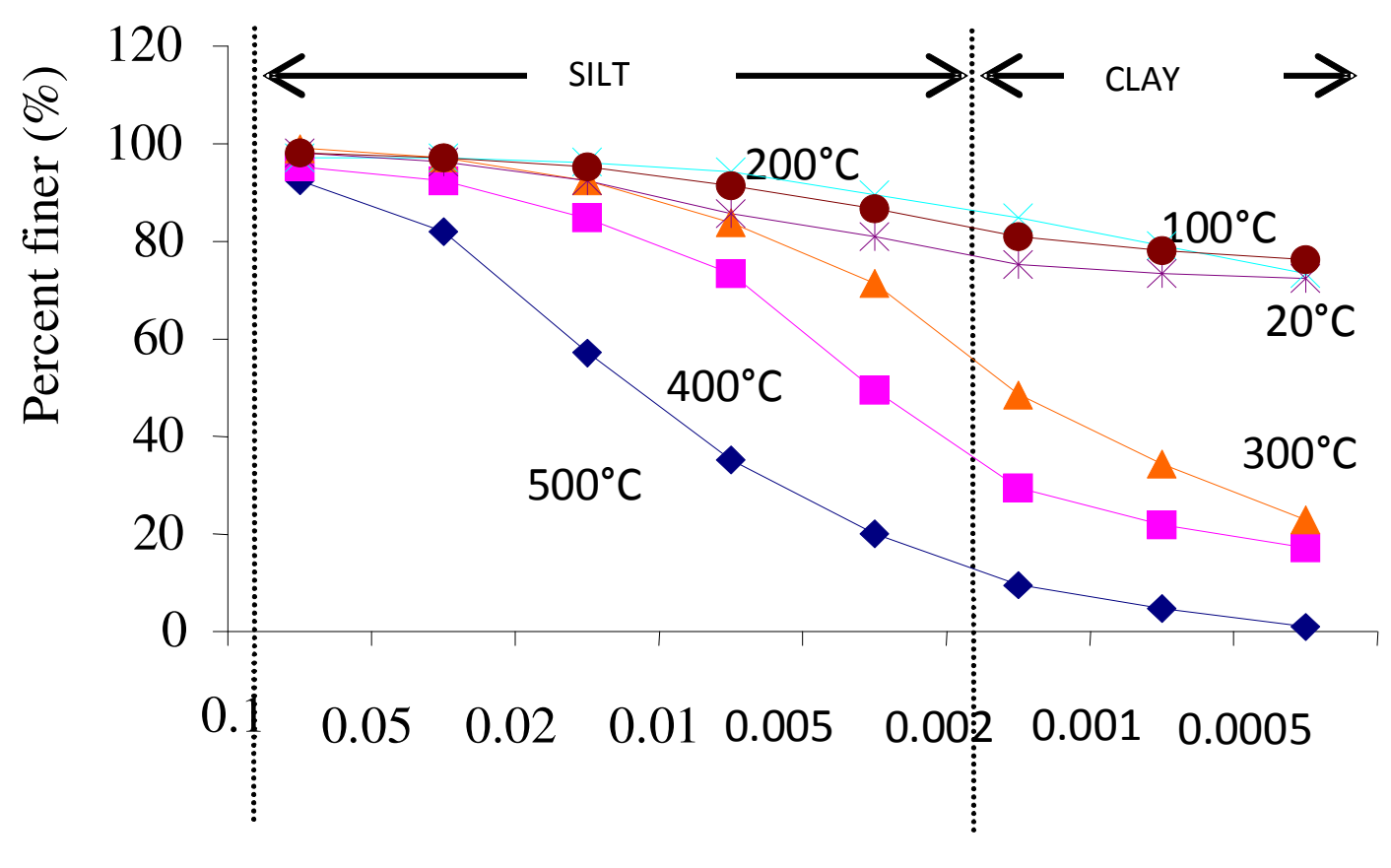

Diameter (mm)

Figure 4. Particle size curves of treated bentonite at different temperatures.

in Figures 3 and 4. Figure 3 shows that heating kaolinite to $200^{\circ} \mathrm{C}$ results in a slight reduction in particle size. The reduction in grain size could be attributed to shrinkage and disintegration of soil particles caused by complete removal of absorbed water (Wang et al., 1990). The particle size curve of bentonite is given in Figure 4. Drastic change in particle size takes place between 300 , 400 and $500^{\circ} \mathrm{C}$. Clay contents of kaolinite and bentonite decrease after $200^{\circ} \mathrm{C}$ (Figures 3 and 4). The effect of thermal treatment on clays is dependent partially on the particle size composition. The soil with granular skeleton is defined by a combined volume of silt-clay plus associated maximum in situ water content that is smaller than the intergranular spaces left free by the skeleton. As for soils without a granular bearing skeleton, the least desirable are the silts that change from a semisolid 


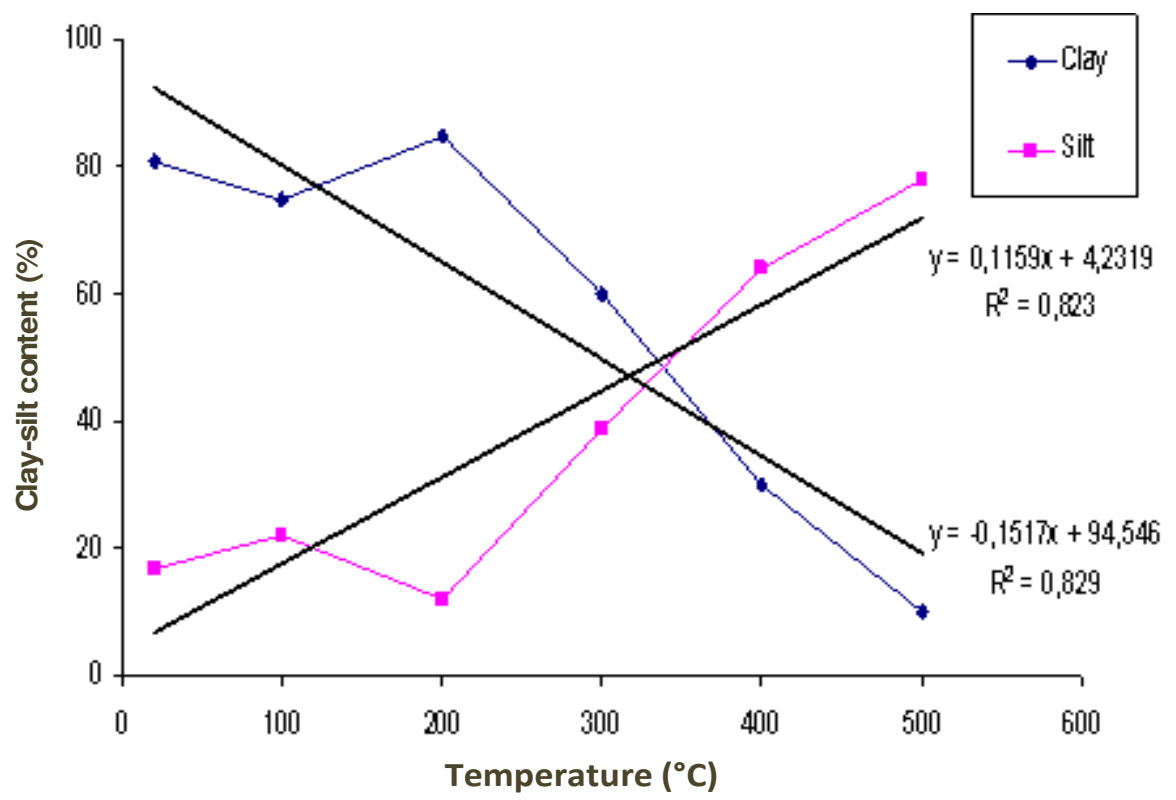

Figure 5. Relationship between clay-silt size contents and temperature for kaolinite.

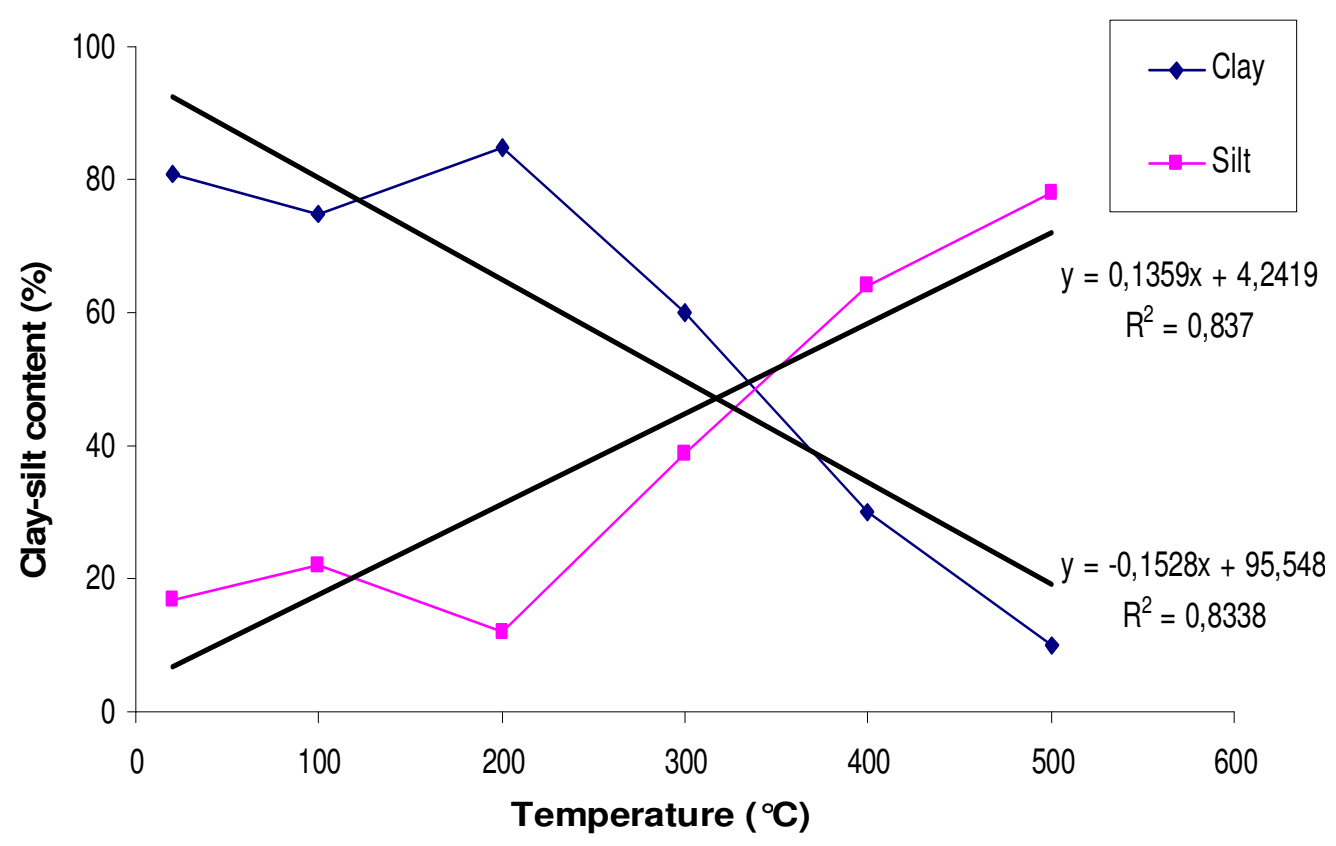

Figure 6. Relationship between clay-silt size contents and temperature for bentonite.

to liquid state at a small increase in moisture content. The greater the clay content and its water affinity of a soil, the smaller the change of its consistency with an increase in water content (Fang and Daniels, 2006). The removal of adsorption water around particles leads to particle growth to larger sizes.

On the contrary, the silt content starts to rise at $200^{\circ} \mathrm{C}$ and reach its maximum at $500^{\circ} \mathrm{C}$ for kaolinite (Figure 5) (Yilmaz, 2004). As can be seen in Figure 6 bentonite shows a similar behavior as kaolinite.

Statistical analysis of experimental results (clay-silt size, uniformity coefficient, specific gravity and activity)

Linear and logarithmic functions can describe the relationships between silt and clay content, specific 


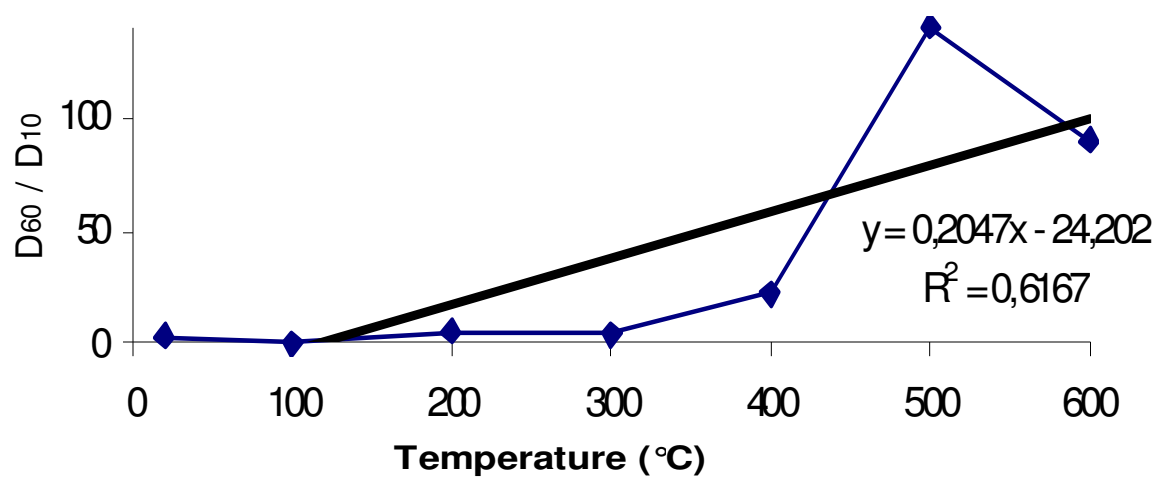

Figure 7. Variation of uniformity coefficient $\left(\frac{D_{60}}{D_{10}}\right)$ with temperature for kaolinite.

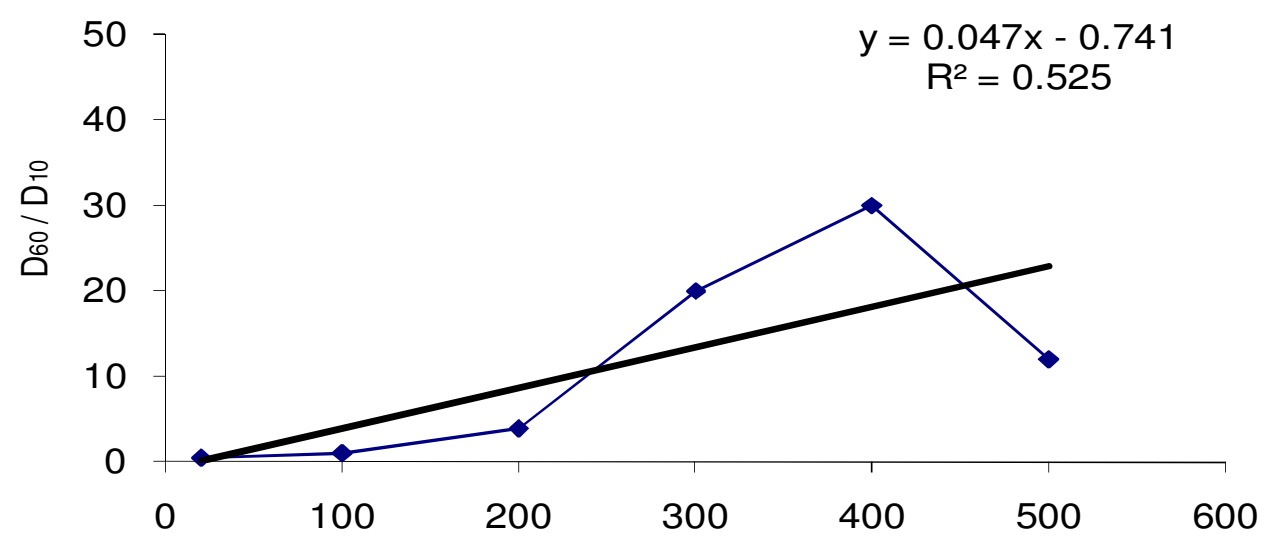

Temperature $\left({ }^{\circ} \mathrm{C}\right)$

Figure 8. Variation of uniformity coefficient $\left(\frac{D_{60}}{D_{10}}\right)$ with temperature for bentonite.

gravity, activity, cohesion, compression index, shearing resistance and temperature for thermal treated kaolinite and bentonite. The regression analysis of clay-silt size equations of kaolinite are as follows (Figure 5):

$\%$ Silt $=0.1159 \mathrm{~T}+4,2319\left(R^{2}=0.823\right)$

$\%$ Clay $=-01517 \mathrm{~T}+94,546\left(R^{2}=0.829\right)$

In these equations, $\mathrm{T}$ is temperature $\left({ }^{\circ} \mathrm{C}\right)$.

If the correlation value is greater than 0.90 , there is a strong linear relationship between two parameters. For the curves of bentonite the regression analysis of clay-silt size equations are as follows (Figure 6):

$\%$ Silt $=0.1359 \mathrm{~T}+4,2419\left(R^{2}=0.837\right)$

$\%$ Clay $=-01528 T+95,548\left(R^{2}=0.833\right)$
Uniformity coefficient $\left(\frac{D_{60}}{D_{10}}\right)$ values increased after 300 and $200^{\circ} \mathrm{C}$, for kaolinite and bentonite respectively. The regression analysis equations of both materials are as follows (Figures 7 and 8):

$\frac{D_{60}}{D_{10}}=0.0473 \mathrm{~T}-0,7418$ (bentonite) $\left(\mathrm{R}^{2}=0.525\right)$

$\frac{D_{60}}{D_{10}}=0.2047 \mathrm{~T}-24,202$ (kaolinite) $\left(\mathrm{R}^{2}=0.617\right)$

Figure 9 shows the change of specific gravity values with respect to temperature for both materials. Kaolinite did not indicate a change in specific gravity. For bentonite the regression analysis equation is as follows (Figure 9): 


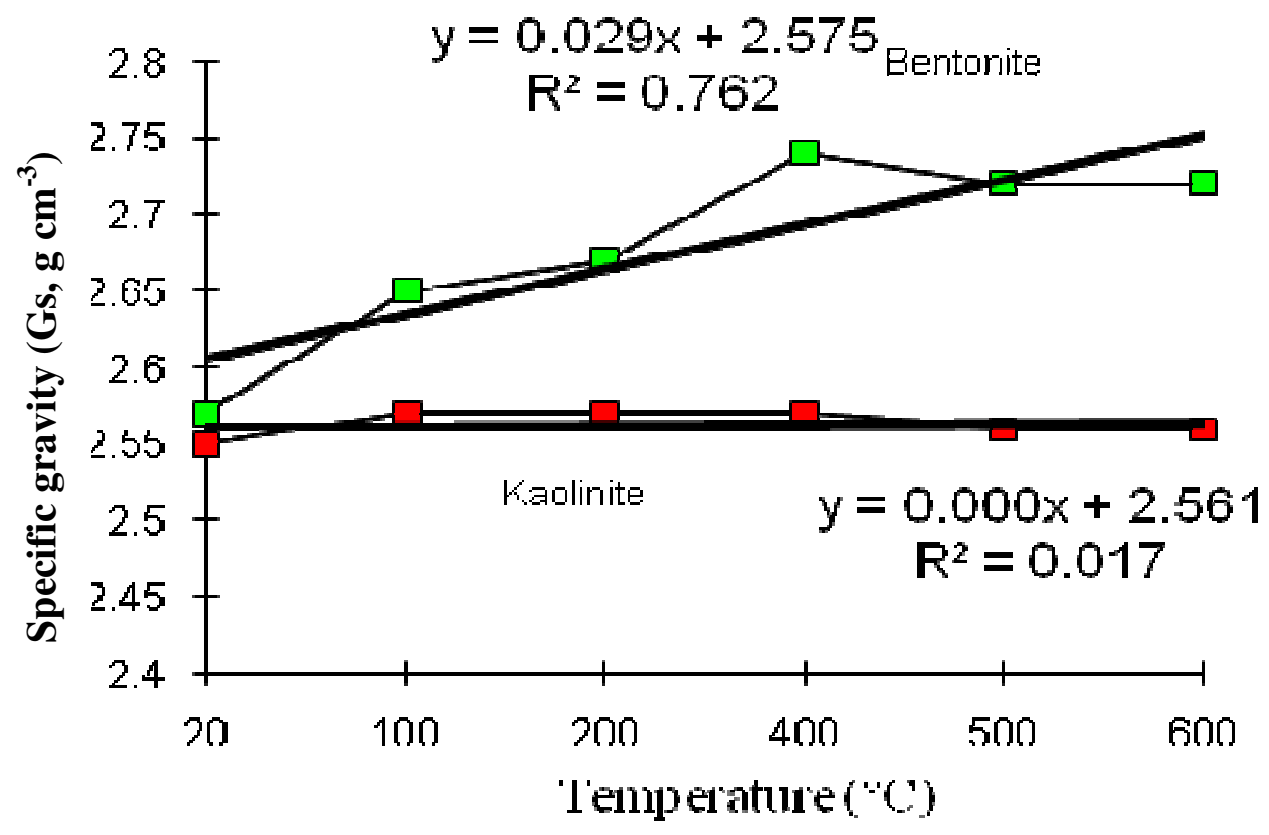

Figure 9. Variation of specific gravity for kaolinite and bentonite with temperature.

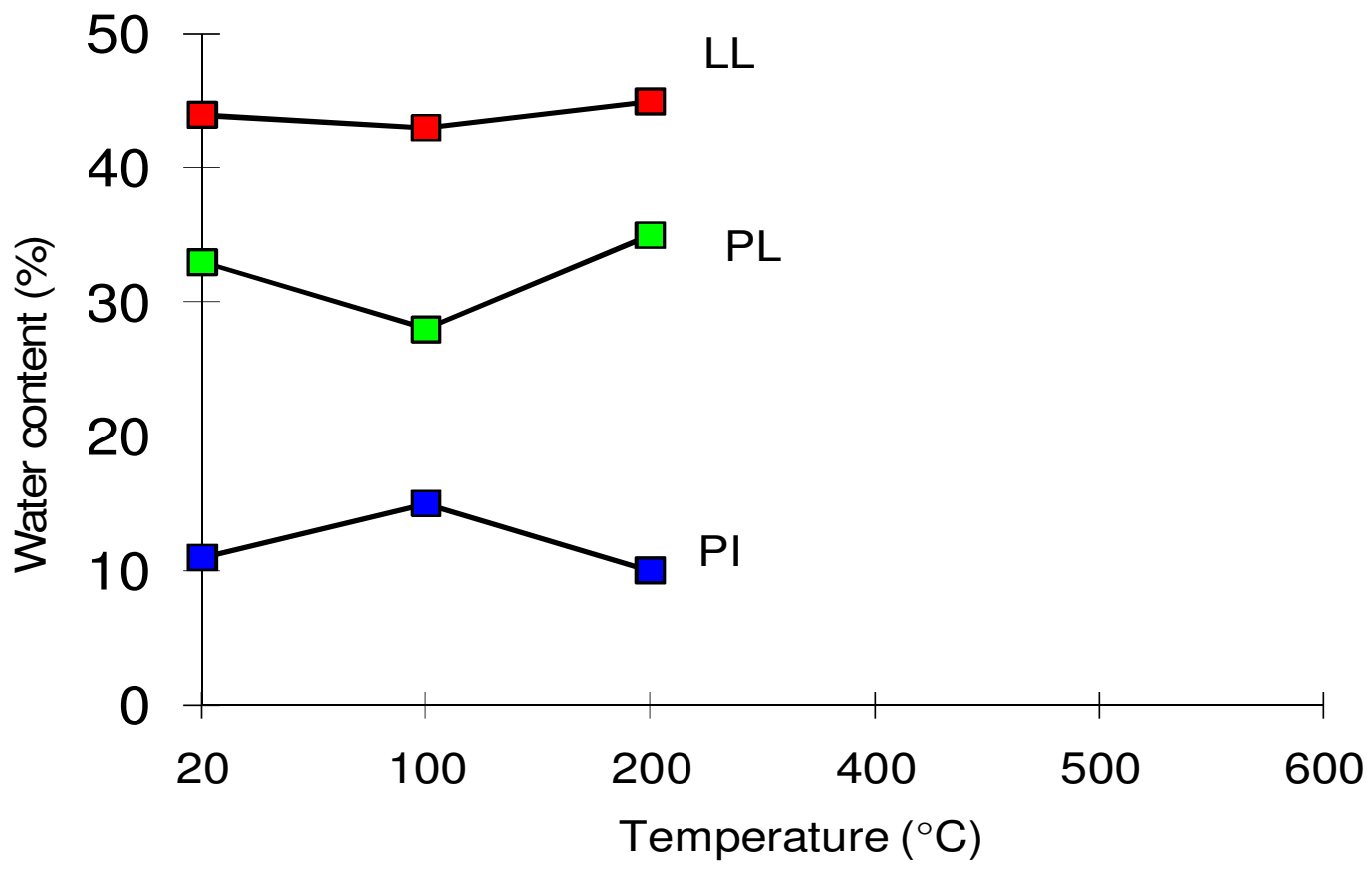

Figure 10. Atterberg limits values and temperature relationship for kaolinite (Yilmaz, 1999).

Gs $=0,00294 T+2,5753$ (bentonite) $\left(R^{2}=0.762\right)$

There is moderate relationship between the two parameters.

The thermal treatment effects on the Atterberg limits of kaolinite are given in Figure 10. Since kaolinite became non-plastic above $400^{\circ} \mathrm{C}$ only the values of 20,100 and $200^{\circ} \mathrm{C}$ were determined. On the other hand, in the case of bentonite, Atterberg limit values decrease with increasing temperature. Above $400^{\circ} \mathrm{C}$, bentonite becomes non-plastic (Figure 11). It can be seen that the activity index $(A)$ value decreases from 1.53 down to 0 for bentonite and does not indicate any change for kaolinite remaining at 0.20 (Figure 12). For bentonite the regression analysis equation is as follows (Figure 12): 


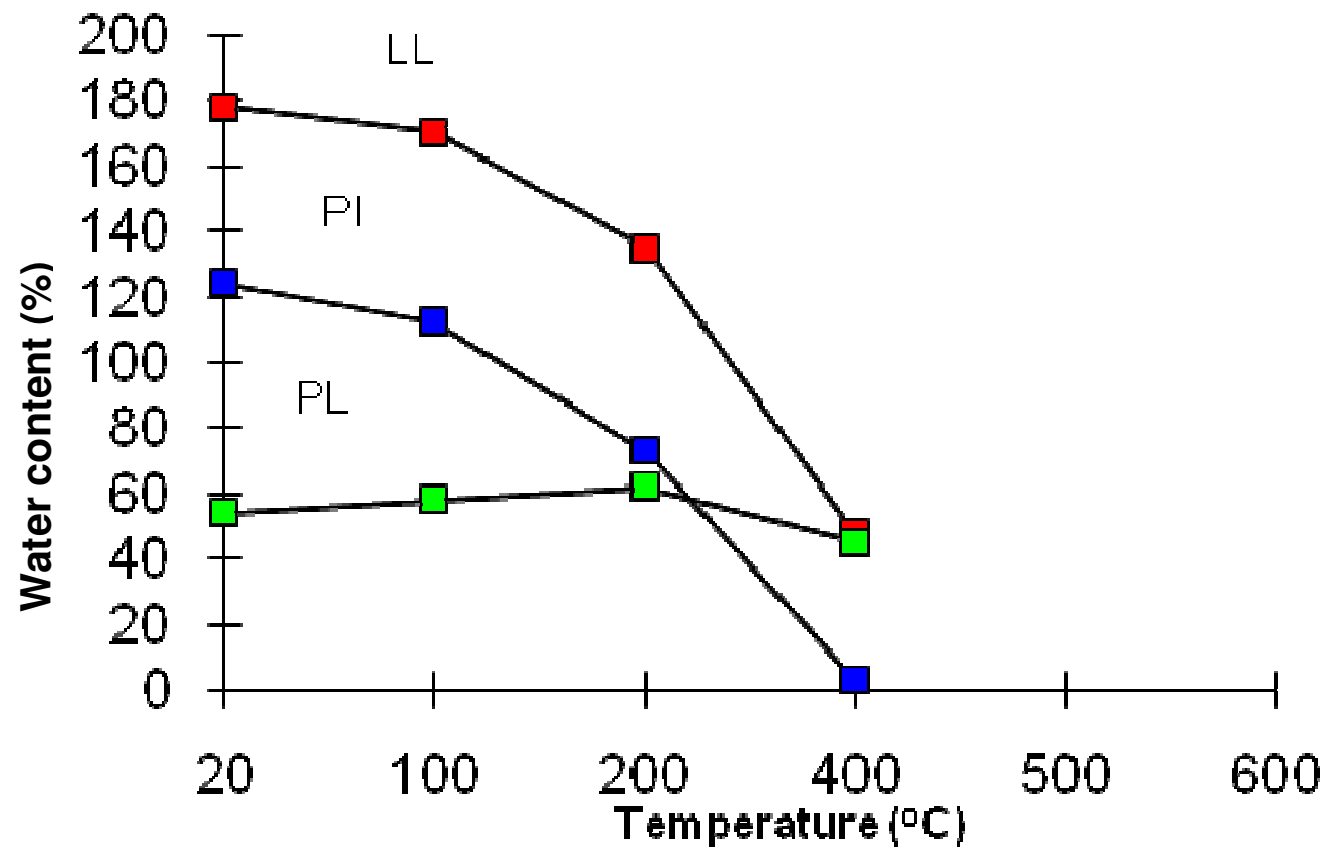

Figure 11. Atterberg limits values and temperature relationship for bentonite (Yilmaz,1999).

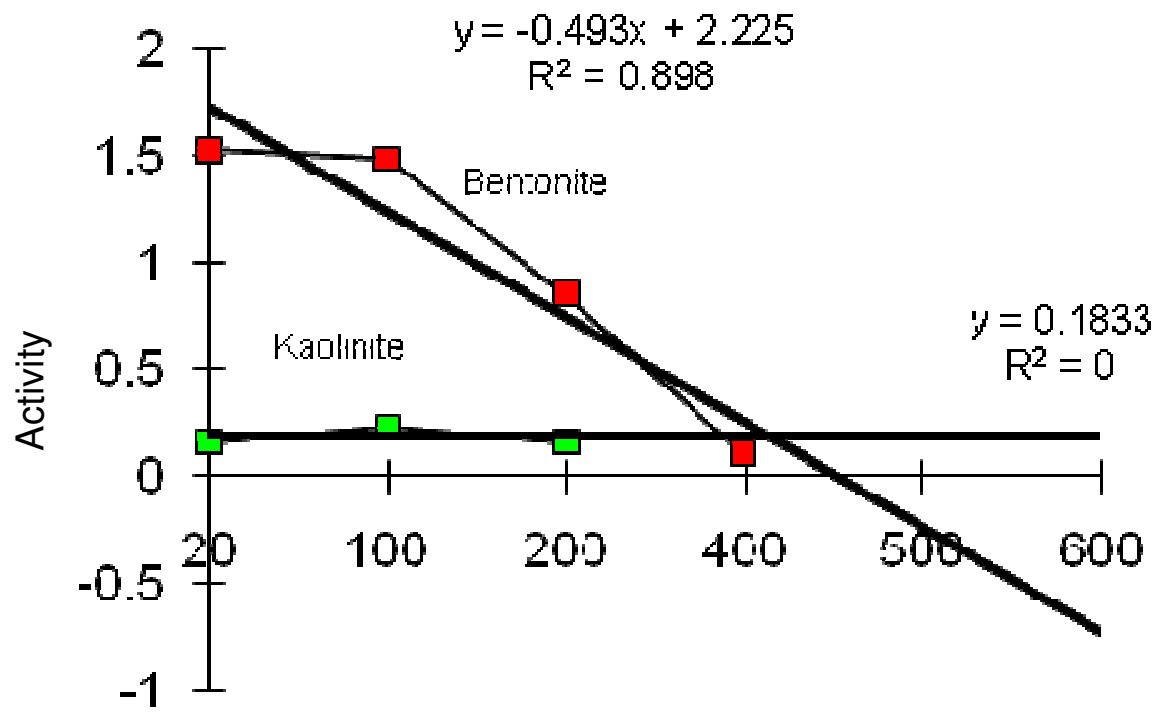

Tomperature ( $\mathrm{C}$ )

Figure 12. Activity and temperature relationship.

$A=-0,493 T+2,225$ (bentonite) $\quad\left(R^{2}=0.898\right)$

It can be concluded that a strong relationship between two parameters exist.

\section{Compressibility and strength properties}

Thermal treatment is defined as an irreversible and effective increase of the shear strength of soil. Some experimental work reported by some researcher, the thermal treatment (temperature range 200 to $600^{\circ} \mathrm{C}$ ) of kaolinite results in a permanent increase of shear strength. The swelling potential of expansive clays depends on the reduction of overburden stress, unloading conditions, or exposure to water and increases in moisture content (Yilmaz, 2009). In order to determine compressibility-swelling properties, the material must still 


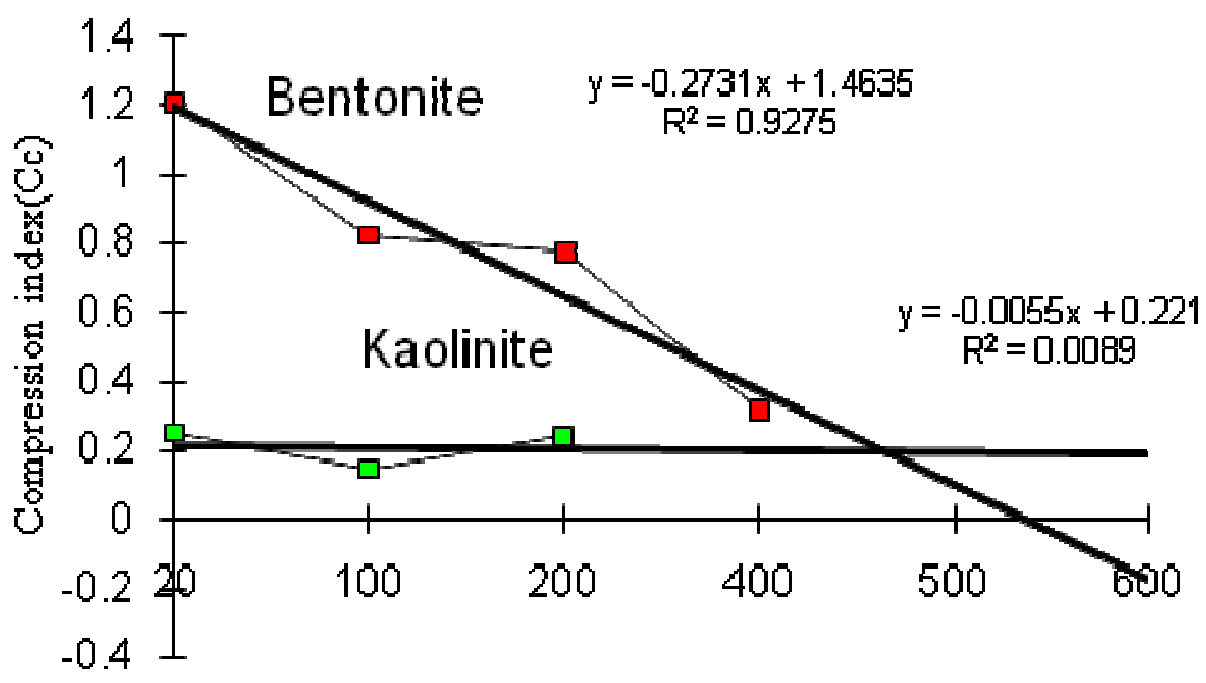

Temperature $\left({ }^{\circ} \mathrm{C}\right)$

Figure 13. Compression index and temperature relationship.

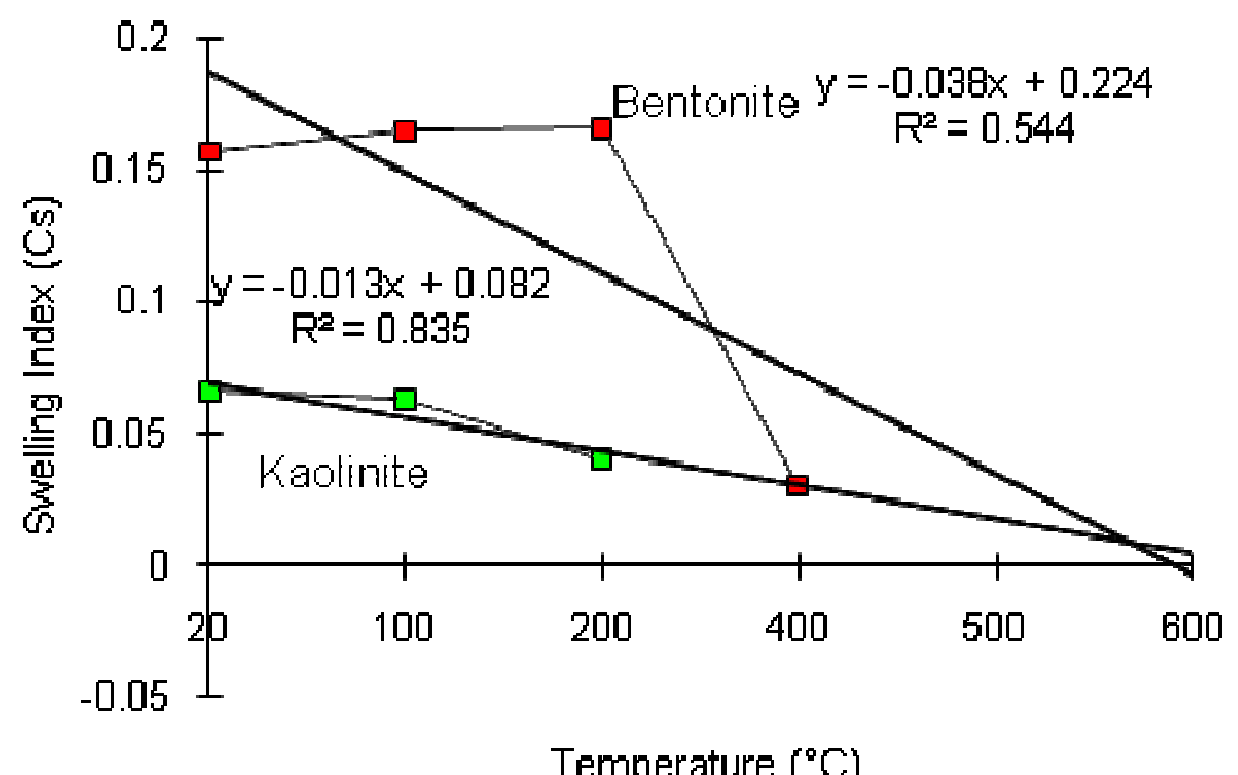

Figure 14. Swelling index and temperature relationship.

be plastic. Therefore, $200^{\circ} \mathrm{C}$ for kaolinite and $400^{\circ} \mathrm{C}$ for bentonite are very suitable temperatures for the odometer test (ASTM D-2435, 1986). Since bentonite has higher water content, the compressibility rate decreases with increasing thermal treatment. In the case of kaolinite the compression index value (Cc) does not show a noticeable variation because of its different layer structure (Figure 13). The decrease in swelling index (Cs) with thermal treatment is shown in Figure 14. Triaxial compression tests (with 68, 95, 172, 38 and 275, 80 $\mathrm{kN} / \mathrm{m}^{2}$ confining pressures) were carried out to determine heating effects on the strength parameters of treated samples.

Removal of water by thermal treatment causes decrease in cohesion values (Figure 15).

\section{Statistical analysis of experimental results (compressibility and strength)}

The change of compressing index and swelling index values as obtained for bentonite (Figures 13 and 14) 


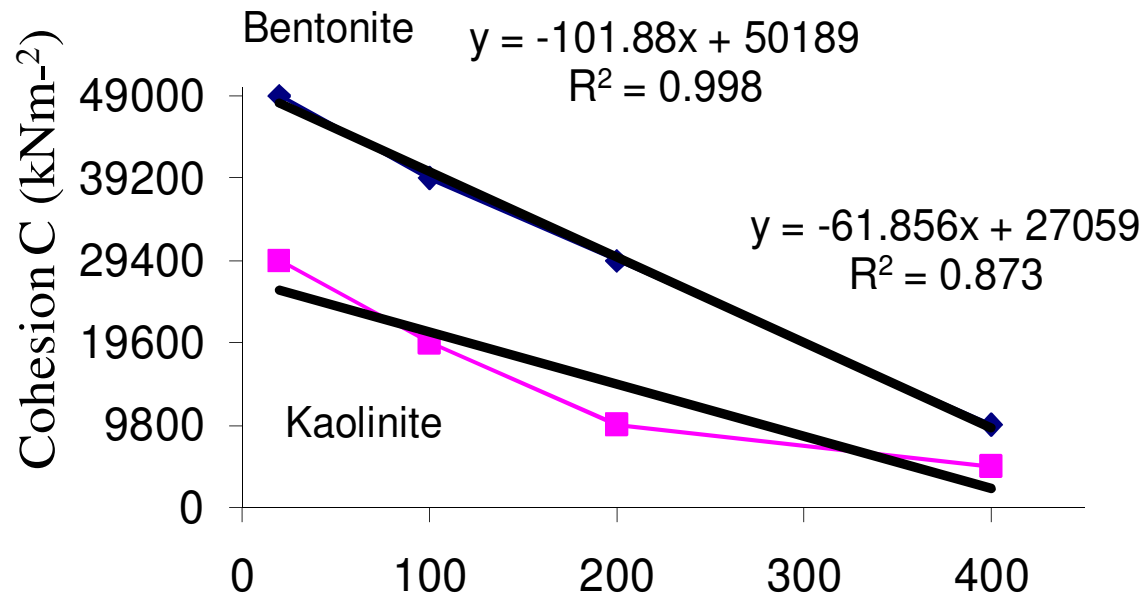

Temperature $\left({ }^{\circ} \mathrm{C}\right)$

Figure 15. Variation of cohesion with temperature.

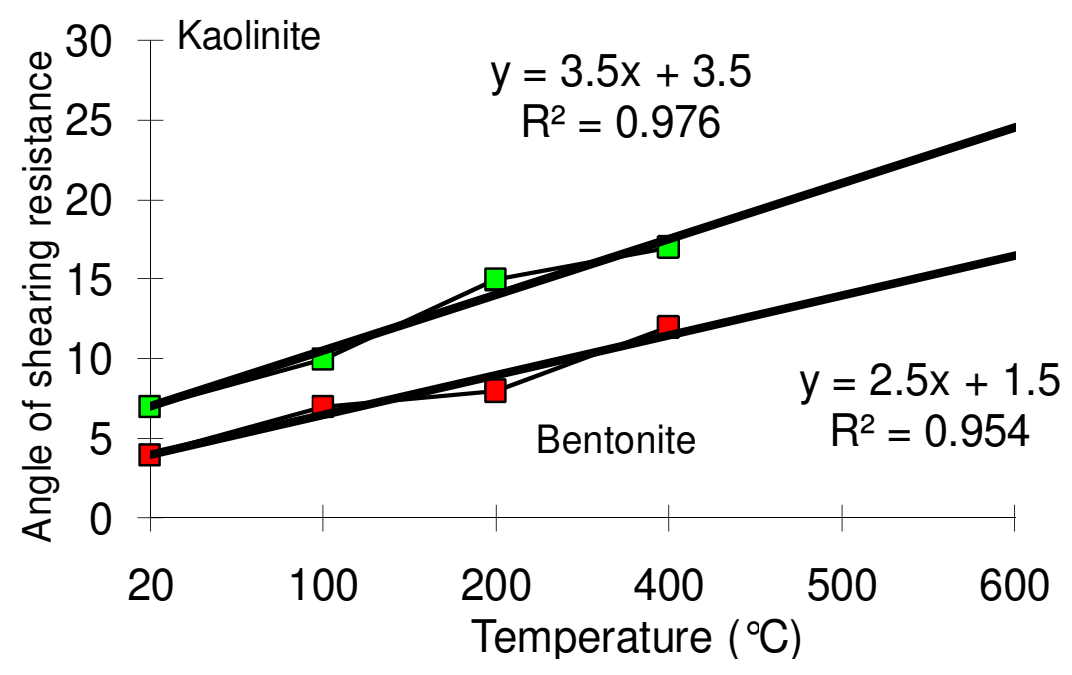

Figure 16. Variation of angle of shearing resistance with temperature.

could be given with the following regression equations:

Cc $=-0,2731 \mathrm{~T}+1,4635$ (bentonite) $\left(R^{2}=0.927\right)$

Cs $=-0,038 T+0,2245$ (bentonite) $\left(R^{2}=0.544\right)$

Cc $=-0,0055 T+0,2210$ (kaolinite) $\left(R^{2}=0.008\right)$

Cs $=-0,013 T+0,0823$ (kaolinite) $\left(R^{2}=0.835\right)$

There is a strong relationship between compression index and temperature for bentonite. Figure 15 shows the change of cohesion values with respect to temperature for both materials. The regression analysis equations of both materials are as follows (Figure 15):
$C=-101,88 T+50,189$ (bentonite) $\left(R^{2}=0.998\right)$

$C=-61,856 T+27,059$ (kaolinite) $\left(R^{2}=0.873\right)$

Angle of shearing resistance $(\phi)$ increases from $100^{\circ} \mathrm{C}$ for kaolinite and $200^{\circ} \mathrm{C}$ for bentonite. The relationship between angle of shearing resistance and thermal treatment is as follows (Figure 16):

$(\phi)=2,5 T+1,5$ (bentonite) $\left(R^{2}=0.954\right)$

$(\phi)=3,5 T+3,5$ (kaolinite) $\quad\left(R^{2}=0.976\right)$

Strong correlations between the angle of shearing resistance and thermal treatment of both materials and 
correlation coefficients have been demonstrated. The angles of shearing resistance depend on grain size distribution of thermal treated kaolinite and bentonite.

\section{Conclusions}

The effects of thermal treatment on kaolinite and bentonite behavior are characterized by non-linearity and irreversibility. Thermal treatment of kaolinite and bentonite specimens causes radical changes of their mineralogical, physical and mechanical properties.

i) Thermal treatment results in the formation of larger clay/silt particles. Kaolinite becomes non-plastic when treated to $400^{\circ} \mathrm{C}$ and bentonite when treated to $500^{\circ} \mathrm{C}$.

ii) In odometer tests performed on specimens treated to various temperatures, the decrease in the compression index of bentonite specimens is significant. Compression properties of bentonite specimens change when treated, whereas the change for kaolinite is negligible.

iii) Cohesion and angle of shearing resistance values are found to change drastically when specimens are treated. Strong correlation coefficients were determined between the angle of shearing resistance and thermal treatment of both materials.

iv) Thermal treatment effects on the behavior of clays are important at places where clay is exposed to elevated temperatures during a long period of time.

v) Therefore, it might be interesting to investigate combined effects of stress and temperature on clays in future.

\section{REFERENCES}

American Society for Testing and Materials (1986). Annual Book of ASTM Standards, D2216-05 Standard Test Methods for Laboratory Determination of Water (Moisture) Content of Soil and Rockby Mass. Philadelphia, PA. pp. 4-8.

American Society for Testing and Materials (1986). Annual Book of ASTM Standards, Annual Book of ASTM Standards, D854-10 Standard Test Methods for Specific Gravity of Soil Solids by Water Pycnometer, Philadelphia, PA. pp. 4-8.

American Society for Testing and Materials (2007). Annual Book of ASTM Standards, D421-85

Standard Practice for Dry Preparation of Soil Samples for Particle-Size Analysis and Determination of Soil Constants, Philadelphia, PA. pp. 4-8.
American Society for Testing and Materials (2007). Annual Book of ASTM Standards, D422-63 Standard Test Method for Particle-Size Analysis of Soils, Philadelphia, PA. pp. 4-8.

American Society for Testing and Materials (1986). Annual Book of ASTM Standards, D4318-10 Standard Test Methods for Liquid Limit, Plastic Limit, and Plasticity Index of Soils, Philadelphia, PA. p. 4-8.

American Society for Testing and Materials (1986). Annual Book of ASTM Standards, D698-07e1 Standard Test Methods for Laboratory Compaction Characteristics of Soil Using Standard Effort (12 $400 \mathrm{ft}-$ $\left.\mathrm{lbf} / \mathrm{ft}^{3}\left(600 \mathrm{kN}-\mathrm{m} / \mathrm{m}^{3}\right)\right)$ Philadelphia, PA. pp. 4-8.

American Society for Testing and Materials (1986). Annual Book of ASTM Standards, D2435-04 Standard Test Methods for OneDimensional Consolidation Properties of Soils Using Incremental Loading Philadelphia, PA. pp. 4-8.

Bhatnagar JM, Goel RK (2002). Thermal changes in clay products from alluvial deposits of the Indo-Gangetic plains, Const. and Build. Mat., (16): 113-122.

Chandrasekhran EC, Boominathan S, Sadayan E, Narayanaswami KR (1969). Influence of Heat Treatment on the Pulverization and Stabilization Characteristics of Typical Tropical Soils. Special Report No, Highway Research Board, Washington, DC, 103: 1161-1172.

Craig RF (1992). Soil Mechanics, 5 th ed., ELBS and Chapman \& Hall.

Dussealut MB, Wang Y, Simmons JV (1988). Induced stresses near a fire flood front., AOSRT a J. Res., 4:153-170.

Fang HY, Daniels JL (2006). Engineering an Environmental Perspective, Taylor and Francis, New York, NY p.10016.

Heller-Kallai L (2006). Handbook of Clay Science, Chapter 7.2, Edited by F.Bergaya, B.K.G.Theng and G.Lagaly, Developments in Clay Science, Elsevier Ltd. 1.

Laloui L, Cekerevac C (2003). Thermo-plasticity of clays: An isotropic yield mechanism. Comp.and Geotech. (30): 649-660.

Laloui L, Modaressi H (2002). Modelling of the thermo-hydro-plastic behavior of clays. In: Hoteit $\mathrm{N}$, editor. Hydromechanical and thermohydromechanical behavior of deep argillaceous rock, Balkema; p.161- 170.

Litvinov IM (1960). Stabilization of Settling and Weak Clayey Soils by Thermal Treatment, Special Report No. Highway Research Board, Washington, DC, 60: 94-112.

Mitchell JK, McMillan JC, Green SL, Sisson RC (1982). Field testing of cable backfill systems. In:Boogs SA, et al.editors. Underground cable thermal backfill. NewYork:Pergamon Press, p. 19-33.

Wang MC, Benway JM, Arayssi AM (1990). The Effect of Heating on Engineering Properties of Clays, Physico-Chemical Aspects of Soil and Rel. Math., ASTM STP Philadelphia, 1095: 1139-1158.

Yilmaz I (2009). Swell potential and shear strength estimation of clays. Applied Clay Science, (46):376-384.

Yilmaz G (2003). Temperature Effects and Shrinkage Properties on Clays, J. of Am. Soc. Cer. Bull., (82):12; 9601-9605.

Yilmaz G (1999). The Effect of Heating on Engineering Properties of Kaolinite and Bentonite, 9. National Clay Symposium, 15-18 Sep. Istanbul, Turkey, pp. 225-232 (in Turkish).

Yilmaz G (2004). Mechanical and microstructural properties of heated and pollutedkaolinite and bentonite. Key Eng. Mater., 1657-1660. 